Article

\title{
National Identities: Temporality and Narration
}

\author{
Carsten Humlebæk \\ Department of Management, Society and Communication, Copenhagen Business School, \\ DK-2000 Frederiksberg, Denmark; cjh.msc@cbs.dk
}

Received: 13 July 2018; Accepted: 16 September 2018; Published: 20 September 2018

check for updates

\begin{abstract}
National identities are social phenomena with concrete—both political and social—effects in society, but a fundamental part of their constitution takes place through narratives about the collective. The existence of collective identities thus depends on drawing boundaries between the collective 'we' and the 'others', as well as on disseminating coherent ideas about the fundamental identity of the we-group. These narratives thus constitute a privileged object for investigating how collective identities are constructed and legitimised in a discourse that places the collective in time, that is, with a coherent and logical narrative about the past and a trustworthy projection into the future. This article defends, first, the concept of the 'master narrative' as a useful analytical category for investigating how national history is constructed, and, second, the concepts of 'sites of memory' and 'Vergangenheitsbewältigung' as means of accessing this narrative. These concepts represent instances of creation and rewriting, respectively, of the narrative and are thus useful tools for analysing how a sense of connectedness with the community through time is created: that is, how a sense of continuity with certain distant epochs is conveyed, and how, on the other hand, a sense of discontinuity with other periods is favoured.
\end{abstract}

Keywords: national identity; master narrative; imagined communities; temporality; lieux de mémoire; Vergangenheitsbewältigung

\section{Introduction}

Nations are collective identities, and, as such, social phenomena with real, concrete social, and political effects in society, but a central part of their constitution very often happens through narratives about the collective. In these cases, the existence of collective identities thus depends on drawing borders between the collective 'we' and the 'others' through narratives and the spread of coherent ideas about the fundamental identity of the we-group among the members of the collective itself, as well as among the 'others' for that matter. The argument here is not that these narratives are the only or even the most important part of constructing a nation's identity, but simply that they often enough constitute one of the mainstays of the (re)formation of national identity. As such, they are interesting for investigating how collective identity phenomena are constituted and legitimised in a discourse that places the collective in time with a coherent and logical narrative about the past and a trustworthy projection into the future.

This article defends and explains the concept of the 'master narrative' as a useful category of analysis for studies on how collectives are legitimised and on how the narratives about the collective are created and change over time. By historical master narrative is understood a coherent and unambiguous historical representation that is socially dominant within the community to which it refers. It is a comprehensive account that arranges and structures the self-image in which the community wants to mirror itself. By ordering all of the minor narratives about the collective, the master narrative creates a coherent network of historical interpretations that is meant to help understand the formation of the collective identity (Jarausch and Sabrow 2002, pp. 16-18). The concept 
has been used particularly in the discussion of the historical identity of nations, but also in other types of collectives, such as the European Community or even the slaves or the disabled ${ }^{1}$.

After an initial discussion of the origins and history of the concept of the master narrative, I concentrate on two adjoining concepts because they are suitable for approaching the core of the master narratives. First, I discuss the French historian Pierre Nora's 'sites of memory' [lieux de mémoire], because they in a very direct way represent or relate to the master narrative and thus give access to key elements of it. Second, I concentrate on the so-called processes of Vergangenheitsbewältigung, or coming to terms with the past, because when a significant part of the collective feels the need to settle scores with the past, this process is almost by definition associated with a rewriting of the master narrative. The past mentioned in such a narrative is precisely not the past as such but the story about it, which no longer feels complete or fair such that story must be rewritten. This text draws primarily on examples taken from Spain, because Spanish history-with a long-lasting, successful dictatorship followed by a negotiated transition to democracy—makes it an interesting case for investigating master narratives. The German and Polish cases are also included, however, but only because these countries constitute particular reference points in Spanish debates or because Spain is a particularly important point of comparison for the country in question. It should be noted that the article focuses on Western nationalism and therefore does not discuss other forms of nationalism and their development. Nations outside the so-called West have developed different approaches to nationalism and national identity, but these are not part of the focus of this article.

\section{Collective Identities in Time: The Concept of Master Narrative}

Just as important as drawing borders between the collective 'we' and the 'others' is projecting this identity backward in time through the construction of a particular history that represents the past of the we-group in a coherent and continuous way. Through such historical master narratives, people make sense of the past and identify with particular versions of it, but the sense-making and identification that the narrative is supposed to further is first and foremost related to the present, and there is something eminently political about this use. It is clear that images of the past are tied up with contemporary politics. Not only are constructions of the past expressions of political interests in the present, they are a constituent part of any power position. Power is constituted, among other things, through the ability to decide which narratives about the past are to be dominant (Olick 2003, p. 261).

The fact that the national community is 'imagined', as stated in the famous book by the British anthropologist (Anderson [1983] 1991), and in that way socially constructed, however, confers on it a fundamental fragility. When the very foundations of the community rest on ideas about community among the population, there is nothing inherently solid or permanent about any given national community. Perception of these qualities has to be created through narrative, and that such narratives are quite common is proved by frequent resort in nationalist discourse to one or more of the notions of antiquity, permanence, solidity, coherence, and continuity. From this necessity follows the centrality of the idea in much nationalist discourse that the imagined community has historical roots and the claim that its fundamental characteristics have remained the same over a period of time, which may be shorter or longer depending on the community. While some communities emphasise some kind of rupture as the origin, others may place their origins in antiquity, but the point is that there will be an idea about a history and a historical narrative. A good way to investigate the nature of collective identities, such as, for example, national communities is thus to focus the analysis around the narrative

1 For a study of German problems identifying master narratives, see Jarausch (2004). For a comparison of post-1989 Bulgarian and German master narratives, see Grosescu (2017); for a discussion of the Georgian master narrative during and after Soviet times, see Chikovani (2012); for at study of Romanian master narratives during the 1970s and 1980s, see Corduneanu (2003). Clemens (2016), by contrast, uses the concept to discuss the forging of a European identity in the 1950s. For a discussion of the historical master narratives of slavery, see Clifton and Van De Mieroop (2016), and for a study on the master narratives of disability, see Hernández-Saca (2016). 
structures that place the collective in its history. The concept of the historical master narrative precisely links the analysis of historiography and the political use of history with an investigation of narrative structure and the logic of the narration.

The origins of the concept are found in the postmodern debate on the narrative character of history as a scientific discipline in the 1970s and 1980s, along with a general criticism of the idea of the master narrative. A master narrative has come to mean the unambiguous historical representation, generally of a nation-state, that is socially dominant and the interpretation of which is not doubted by the population. The American historian Hayden White originated the debate on the fundamentally narrative character of history writing in his Metahistory, in which he showed that historical accounts responded to a series of narratives tropes (White 1973). However, towards the end of 1970s, the very concept of great narratives [meta récits] was rejected altogether by postmodern deconstructivist philosophy, among others by Jean-François Lyotard. According to Lyotard, postmodern society was characterised by a general distrust in all 'great narratives', such as, for example, the Enlightenment, the belief in the future, or Marxism, all of which had been fundamental for the development of modernity, in itself a kind of meta narrative. It is also worth noting that this critique is especially-and perhaps only-relevant for Western societies that had experienced the development of modernity in one way or another. Lyotard's radical philosophical critique was aimed at all great narratives, but especially the ideologically charged narratives, and, as such, was a rejection of their political nature and the instrumentalisation that they imply. Indeed, Lyotard rejected the possibility of any totalising historical interpretation (Lyotard 1979). The poststructuralist critique of great narratives did not mean that such narratives ceased to exist, but it highlighted the necessity of being aware of the political implications that they entail and pointing the analytical lens in that direction.

The revival of the master narrative as an analytical concept in the 1990s seems to be connected with the disappearance of the Iron Curtain because it proved useful for conceptualising the changes that the end of the Cold War imposed on the countries, especially in Eastern Europe. With the breakdown of the Communist regimes, the majority of Eastern European countries also lost their regime-related historical master narratives, and both new elites, as well as the broader populations, were bound to search for new ways of understanding the past in each of these countries. ${ }^{2}$ The reunited Germany, and its twentieth century history-including over four decades of division into a Soviet satellite and a Western capitalist state-was a case in point of that period's urgent need to make new sense out of the past (Jarausch and Sabrow 2002, pp. 21-22).

For these reasons, there is a German influence in the development of the concept of the historical master narrative, but the passage of the concept back into historiography was also spurred by the work of the American philosopher of history Allan Megill, among others. Megill operationalised the concept as a tool for historiographical self-reflection by distinguishing between various types of narratives. Referring to the above-mentioned postmodern and poststructuralist position denying grand narratives, Megill argued that they could not be replaced by reducing history to memory precisely because of the political implications of historical narratives. He differentiated four different types of narratives: narrative, master narrative, grand narrative, and meta-narrative. Beginning with the last-mentioned item in Megill's typology, a meta-narrative is a story about the narrative or that reflects on the narrative, whereas the grand narratives 'claim to offer an authoritative account about history in general', i.e., a kind of philosophy of history. In comparison, according to Megill, a master narrative claims 'to offer the authoritative account of a certain segment of history' (Megill 1995, p. 152). Such a segment could be, for example, a nation, which is why what Megill terms a master narrative is the most relevant for the purposes of this study. Contrary to the poststructuralist rejection of great narratives, which is understandable as a philosophical imperative, but not very useful as the point of departure

2 For a good comparative study of the post-1989 efforts at reinterpreting national histories and historiographical self-reflection in Eastern and Central Europe, see Hadler (2002). 
for analysis, Megill's typology invites us to acknowledge the political instrumentalisation of certain types of great narratives and use that fact in the analysis. The work of Megill thus helped to make the master narrative a useful concept in historiography, but the further developments happened largely in Germany. Directly inspired by Megill, the German historian Konrad Jarausch has operationalised the master narrative by listing the following characteristics as essential (Jarausch 2002, p. 142). ${ }^{3}$

- It sketches out the general patterns of historical development.

- It offers a simple, basic pattern that is characterised by uninterrupted, progressive development that reflects the true nature of the nation and its 'historical determination'. ${ }^{4}$

- It provides a dramatic representation that plays on all the strings of narrative art and where historical figures appear on a regular basis.

- It conveys an ideological message and thus a particular point of view that encompasses the above-mentioned 'historical determination'.

- Finally, the master narrative serves the formation of collective identity by tying the national identity together with the historical ideals it represents.

A historical master narrative is differentiated from other historical narratives precisely because it claims to represent the central line of development of the community to which it refers, as well as to fulfil an explanatory function concerning the community's future.

The architects of any master narrative are often political and intellectual elites because such a narrative so obviously has a legitimising function: it claims to be the authoritative version of the community's history. Thus, by a master narrative, one understands a comprehensive account that orders all of the minor narratives about the collective, thus creating a coherent network of historical interpretations that serves to form the collective identity. It emphasises the values on which the identity builds and offers models that incarnate the ideals that the collective should seek to live up to.

Although the master narrative presents itself as authoritative, it is not necessarily the only narrative; in fact, there will often be competing or divergent narratives that also claim to be the true narrative. Master narratives do not assert themselves, therefore, through monopolies of interpretation, but through social dominance, and one of the most important ways of determining social domination is to be challenged. National master narratives are also not necessarily inclusive, although they claim to represent the nation. Such a narrative can easily exclude a particular part of the population or include them only under certain conditions. The master narratives of democratic regimes, however, cannot afford to alienate a substantial part of the population, and therefore in such regimes it is often important to create an inclusive narrative.

Analytically speaking, the historical master narrative has four dimensions. First, the narrative has a material aspect that connects, separates, emphasises, and leaves out events, people, and structural relationships. Periods are highlighted and glorified or rejected and deliberately omitted by emphasising continuities and discontinuities. A lineage in terms of events, values, institutions, and ways of organising society taken from national history is constructed, and the national self-image is identified with that lineage. Other events, entities, and values are rejected or silenced as non-essential or even anti-essential to the national 'we'. Second, the theoretical-methodological dimension of the narrative demands a plausible structure for the main argument behind the master narrative, and this structure largely relies on unspoken presuppositions and criteria. Third, the narrative representation of the past appropriates semantic elements while using certain structuring concepts and narrative principles. Fourth, historical texts illustrate the fundamental discursive structure of sense-making in which historical 'reality' is constituted (Middell et al. 2000, pp. 21-27; Jarausch and Sabrow 2002, pp. 16-18).

3 For the history of the concept of the master narrative, see Jarausch and Sabrow (2002). For the crisis of the national master narratives, see Jarausch (2002).

4 There lies no determinism in speaking of 'historical determination', here, only the fact that this discussion is situated at the ideological level of the master narrative, which explains the past/history to indicate a direction in the future. 
With this operationalisation, German historians demonstrate the usefulness of the concept of the historical master narrative as an analytic tool for inquiry into constructions of national history, which are inextricably linked to any national discourse and the building of national identity. To any nation-whether it has a state or not-belongs a history. Studying the historical master narrative, may even aid understanding of the relationship between internal developments within historiography and changes in the public culture of remembrance. The official master narrative of the Franco regime, for example, continued to rely on the victory in the civil war until the end, but this interpretation disappeared almost completely within a very short period after the death of the dictator. Examining the dominant master narratives before and after Franco's death can thus shed light on the shift in memory culture and the legitimisation mechanisms that took place during the change of regime.

\section{The Nation and Its Time: Temporality and Continuity}

Benedict Anderson identified a change in the conception of time as one of the fundamental preconditions that made possible the rise of imagined communities, the 'sprout' of the later nations. This change also led to the creation of the very genre of history as we know it today and the modern museum as the place where history was preserved for posterity. The earlier temporality was characterised by a lack of historical progression and contemporaneity of temporally distant figures and events. Anderson illustrates the phenomenon through religious images, which, throughout the Middle Ages, painted biblical scenes in contemporary dresses; the Virgin Mary, for example, as the daughter of a medieval merchant and precisely not as a girl with Semitic features dressed in clothing typical of the first century. From the pre-industrial, primarily agrarian society's perception of time-where the eternal, cyclical return of the seasons dominated the social order-time became 'linear, homogenous, and empty'. The new temporality was characterised by an idea of the nation (or other collectives for that matter) that moves forward as a single organism from one end of history towards the other in a constant, anonymous, and yet simultaneous manner. Anderson borrowed this idea from the German philosopher Walter Benjamin, who suggested that the religious notions of warning and fulfilment slowly disappeared in favour of a time as measured by clock and calendar (Benjamin in Anderson [1983] 1991, p. 24). The change from a predominantly circular-oral to a linear-written form of historicity naturally resulted in a growing distinction between past, present, and future. These developments increased the role of history and memory as necessary tools of explanation and orientation within the extended spatiotemporal horizon (Anderson [1983] 1991, pp. 22-36; Olick and Coughlin 2003, p. 52).

Historical master narratives are an example of this modern perception of time. Usually a linear, progressive perception of time dominates such narratives, although a closer inspection may reveal 'empty' periods, during which practically nothing seems to have happened, or parentheses of non-existing time. A contemporary example from world history of a 'missing' period is the time between the fall of the Iron Curtain in 1989 and the terrorist attacks in the United States on 11 September 2001. In hindsight, the period lacked a theme that was comparable to the Cold War before 1989 and the War on Terror after 2001. At first glance, nothing seems to have happened during these uneventful periods between two events, which of course is not true. However, the point is that time becomes a semiotic system, differentiating the eventful parts of the past from the uneventful parts. This is a necessary step in the production of history, as it would be impossible to reproduce the past one-to-one. As the French anthropologist, Claude Lévi-Strauss put it:

In so far as history aspires to meaning, it is doomed to select [certain historical periods] ( ... ) and to make them stand out, as discontinuous figures, against a continuity ( . . ) used as backdrop (Lévi-Strauss 1962 quoted in Zerubavel 2003, p. 316).

Although this type of story, in fact, only consists of a series of events, it appears to be a linear and progressive narrative, one that, moreover, has to make sense. It is especially in this type of story-the so-called eventful history-that we find master narratives, because they precisely have to 
outline the longue durée development, point out the nation's 'historical determination', and convey a particular message.

To construct continuity, on the other hand, means to represent distant epochs or events as connected due to their perceived similarity. They are portrayed as continuous, and in this sense they represent the 'real' time and the 'real' sequence of events in the 'real' national history. The period or events in between are either not represented or are represented as deviations, or indeed perversions, of the 'real' course of history, which generally is portrayed as flowing unaltered and unalterable beneath these surface perturbations.

Etymologically, the term continuity comes from the Latin continuus, meaning uninterrupted. This, however, does not mean immobile: it means gradually evolving without perceivable ruptures and thus stresses the continuous flow of time. It is very much in this sense that the German historian Reinhart Koselleck uses the concept in his analyses of historiography. In his view, continuity means continuous change, and it is therefore not a static state, as is often portrayed. In fact, nothing remains static in his model. History is made of various temporal layers, or overlapping historical processes, all of which are in continuous evolution. The speed of change, however, varies from process to process, which creates tensions that can be experienced as crises because the layers get 'out of sync' with each other (Koselleck 2000, pp. 19-26). Koselleck uses this concept to conceptualise historical evolution. According to this idea, historical analysis should focus on the tensions that are created by the friction between the different velocities of development at the various levels.

If we are to operationalise Koselleck's conceptualisation of historical change in the analysis of master narratives, we have look for change within the apparently static and for the similarities and continuities within the apparently discontinuous. In principle, we are to look for these signs in the master narrative, but as this often does not exist as such in the form of one particular representation, we must necessarily turn to representations that are accepted as canonical, and the analysis should contrast several of these sources. The use of Koselleck's concept of continuity as an analytical tool can thus be very useful for analysing the rhetorical construction of the continuities, as well as the opposite - the placement of other historical processes outside historical events—that both populate historical master narratives.

\section{The Nation and Its Memory: Les Lieux de Mémoire}

One of the consequences of the change in historicity was the feeling that the past was perpetually slipping away; according to certain scholars, this resulted in a kind of crisis of memory. The past no longer seemed to be immediately present, but was something that required a constant effort for preservation and recovery. Before these changes, following the French historian Pierre Nora, past and present were experienced as continuous, and memory was thus an integrated part of social life, a situation that he described in positive terms as an 'environment of memory' [milieu de mémoire]. We no longer live in these milieux de mémoire, however, and today a sense of discontinuity prevails. This change of perception, according to Nora, was linked to the emergence of critical historiography that mediated multiple memories instead of one, single, naturally conceived continuity. History became a matter of critical interpretation and the proper subject of historical research, and memory became private knowledge, thus tearing history and memory apart. According to Nora, history predominates over memory in present-day societies, creating the sense of a definitive border between past and present, which he clearly finds regrettable. The past is conceived of as something terminated once and for all. Others, before Nora, had reflected on the consequences of the changed perception of time in relation to the balance between memory and forgetting. The French historian Ernest Renan, in his famous 1882-conference on the conception of the nation, already stressed the oblivion of history, emphasising its necessity for the establishment of a national identity and for a master narrative to work, so to speak (Renan [1882] 1992). There is a clear parallel between Nora's depiction of memory practices and Renan's description of the connection between memory and forgetfulness in the creation 
of nations and national narratives. Renan was not as nostalgic as Nora, however, and accepted the importance of forgetting.

An example from Spain can illustrate that the division between memory and history may not be as clear-cut as Nora depicts it. Shortly after Franco's death, the majority of Spaniards seemed in a hurry to distance themselves from the dictatorship. They focused on the-hopefully-democratic future and celebrated that the dictatorship had definitely become part of history (Humlebæk 2006, pp. 505-511). There was thus a broad social consensus about shifting the focus from memory to history, which Nora was so critical of, i.e., away from the 'environment of memory' that characterised the Franco period. Since 2000, however, there has been a popular movement in the opposite direction in favour of the so-called 'recovery of historical memory'. ${ }^{5}$ The movement is primarily about opening mass graves from the Civil War and the dictatorship and identifying the victims, but also about remembering the crimes of the dictatorship and preserving the memory of the oppressed for posterity; as a result, a wide range of events and people are recovered from the oblivion of history. This adjustment of public memory can be interpreted as an attempt to rewrite the Spanish master narrative that had lost its connection with what the majority of Spaniards felt. To stay in Nora's terms, it is possible to say that with the shift of focus resulting from their successful transition to democracy, the Spanish master narrative had moved so far away from the majority's memories that a demand arose to acknowledge the legitimacy of other narratives. It is doubtful, however, whether it has anything to do with returning to a milieu de mémoire, as Nora seemed to prescribe. Therefore, although Nora may be right in observing some general trends, only very rarely does the distinction between memory and history seem clear, and the desire for a return to past recollection practices is virtually absent.

Focusing on one aspect of memory necessarily results in other areas of memory blurring out of focus (Renan [1882] 1992). According to Nora, we are therefore forced to artificially connect past and present, and represent memory through self-reflexive so-called 'sites of memory' [lieux de mémoire] that can be everything from monumental buildings, monuments, and emblems to commemorations, symbols, rituals, manuals, basic texts, and mottoes. These sites of memory have to create an illusion of continuity:

Lieux de mémoire arise out of a sense that there is no such thing as spontaneous memory, hence that we must create archives, mark anniversaries, organize celebrations, pronounce eulogies, and authenticate documents because such things no longer happen as a matter of course (Nora 1996, p. 7).

Nora thus saw the creation of the lieux de mémoire as a response to the challenges posed by the changed temporality - a last attempt to preserve memory in a society that is dominated by historiography. Their task was to reconstruct an idea of lineage that had been lost and to stop the progression of time through the transformation of past events into eternally present events (Nora 1996, pp. 1-6; 1989, p. 25). Nora embarked on the project of historicising the French lieux de mémoire. The result was a seven-volume work directed by Nora that aimed at being a complete survey of the French heritage of memory (Nora 1984-1992). In spite of its composite nature, Nora's lieux de mémoire arguably represents an attempt to write the French historical master narrative.

As stated above, the whole idea of Nora's endeavour transmits the sense of a melancholic and essentialist attempt at preserving something that has been lost. However, in spite of Nora's nostalgia in relation to the memory of pre-modern times, the very concept of lieux de mémoire nevertheless has been of great importance for the discussion of the links between history, symbols, and collective identities. In relation to the study of individual nations, Nora's study and method thus adds important knowledge about the effect and function of symbols and symbolic practices. 'Sites of memory' represent a kind of nodal point where sense-making and feelings are condensed, because, although symbols appeal to the

5 See, for example, the homepage of the association with the same name: http:/ / www.memoriahistorica.org.es. 
feelings, they often also express a rational calculation among the nationalists who design and/or make use of them.

The value judgement implicit in Nora's nostalgic vision and the vague and very broad definition of the lieux de mémoire project, however, have met with quite a lot of criticism. Among other things, the question of what is not a lieu de mémoire has been raised and Nora's project was criticised for taking the national history of France for granted as an object and subject of memory (Middell et al. 2000, pp. 13-14). Also problematic is the lack of questioning of the so-called 'true' memory practices of pre-modern societies; the contention that history and memory were experienced as the same thing is not discussed. Nora precisely criticised modern historiography for simply aiming to represent the past, although in his conceptualisation of the milieux de mémoire, reputedly only one representation existed. He evaded this question, however, by not being critical of the 'true' memory practices, and in his work there is an insufficient conceptualisation of what such practices consisted. Apparently, Nora's pre-modern, 'true' representation of past and present together did not seem to change over time or to be receptive to new inputs, which contradicts what we know about those periods. ${ }^{6}$

Although the distinction between 'true' and 'modern' practices of memory and history writing is problematic, Nora's study adds important aspects to the knowledge of the workings and functions of memory practices today. As such, the concept of lieux de mémoire is a useful analytical tool. Memories depend on their attachment to a concrete site, a lieu de mémoire, such as, for example, a monument, landscape, or commemoration. The mere existence of such a site, however, does not mean that its meaning is not contested. On the contrary, dispute over the meaning of a lieu de mémoire is a central part of its function, namely that of catalyst of and battlefield for diverging memories. Only through this process of criticising and challenging the established narratives, can the social dominance of a particular interpretation be determined.

\section{Between New and Old Temporalities: Anniversaries and Commemorations}

Following Nora, commemorations are one of the classical types of lieux de mémoire. Due to their value as annually recurring direct representations of history, the power to define which commemorations to celebrate very directly represents instances of the creation or reformulation of the master narrative, and therefore such commemoration are an obvious choice as an object of analysis. As the American and Canadian anthropologists, Gerald Sider and Gavin Smith put it: 'they are attempts at closure, at decisiveness and imposition,' meaning that they very directly attempt to identify the important elements of history and convince the surrounding community about their representation (Sider and Smith 1997, p. 7).

Commemorations constitute multiple sites to which certain values and meanings are attached, and around which the struggle to define history takes place. The struggle has two sides to it, since it not only regards the interpretation and celebration of each anniversary, but also which anniversaries to include in the official calendar of commemorations. In this sense, the calendar can be viewed as 'a social artefact that reflects as well as shapes our collective visions of the past', as noted by the Israeli-American sociologist Eviatar Zerubavel ${ }^{7}$ (Zerubavel 2003, pp. 318-20).

Here, analysis of commemorative activity around the anniversaries is not aimed at reconstructing the commemorated historical event as it actually happened, but instead focuses on the values invested in it, and the continuities and discontinuities constructed through this investment. The anniversaries are thus interesting not because of what they say about the past being commemorated, but precisely for what they reveal about the present, and the relationship between the present and national history.

6 For a thorough and critical reappraisal of Nora's work on lieux de mémoire, see Apor (2001). See also Apor (2002, pp. 8-10) and Till (2003).

7 For a study of the transnational commemorational patterns of the calendars of 191 countries, see Zerubavel (2003). 
When a commemoration of a historical event is established, the event itself loses its processual character and is reduced to a single moment, according to the Haitian historian Michel-Rolph Trouillot. All of the preceding events are placed in a single temporal line leading up to the historical event that is commemorated. Thinking of Koselleck's point of representing historical change as consisting of different layers of separate development patterns, the production of a commemoration requires that intermingled and parallel historical processes are simplified and blended into a single linear continuity. The general historical context thus fades out. Chronology thereby replaces process and strengthens an idea of direction and causality in history (Trouillot 1995, pp. 112-19). These characteristics that Trouillot finds in the creation of a commemoration are also perfectly consonant with Anderson's idea of the increasingly linear time that characterises the rise of the imagined communities, as well as with Nora's contention that lieux de mémoire are created in order to strengthen the perception of lineage, descent, and causality.

Following Trouillot, commemorations represent a narrative of power-the power to decide what is interesting within an historical account. They thereby help to create, modify, or sanction the public meanings that are attached to historical events, and, as such, they are rituals that package history for public consumption. On the one hand, commemorations thus trivialise the historical process by simplifying complex historical processes into one-dimensional moments, and, on the other, they mythicise history by magnifying the importance of certain events, entities, or people. These effects are all functions that are central to the construction of historical master narratives, and commemorative events and rituals remain important elements of such narratives.

Commemorations also contain cyclical elements. Anniversaries and their commemoration portray history as part of the natural cycles of the world, and annual cycles provide a basic element of modern commemorations: an exact date that returns year-by-year. While the process of creating commemorations is characterised by a linear conception of historical time, the function and practice of commemorating an anniversary, paradoxically, is characterised by a cyclical conception. This amounts to a correction of Anderson's conception of the historical time of the nation: it is not only linear but also cyclical. Commemorations, as the celebration of the imagined community, thus also rely on pre-modern conceptions of time. A date anchors an historical event in the present through the simultaneous production of commemorations and silences. Focusing on the historical event, the rest of the historical year being commemorated is obliterated, imposing a silence upon all the events surrounding the one being marked. We, for example, associate the year 1492 only with the so-called discovery of America and maybe the end to the Reconquista with the defeat of the kingdom of Granada. The rest of that year's events and those of the surrounding years 1491 and 1493 are forgotten. 'To show is to conceal' [zeigen ist schweigen], as Koselleck puts it.

The American sociologist Jeffrey K. Olick's uses Mikhail Bakhtin's dialogical concept of genre to convincingly explain the complex relationships between present and past contained in commemorations (Olick 1999). According to Bakhtin, all the utterances take place within unique historical situations, while simultaneously containing 'memory traces' of earlier usages. Referring to commemorations, the 'past includes not only the history being commemorated, but also the accumulated succession of commemorations, as well as what happened between those powerful moments' (Olick 1999, pp. 383-84). This understanding of the genre highlights the role of a commemoration in producing its own circumstances. Earlier commemorations shape later ways of seeing. This approach avoids situating commemorative texts wholly in terms of their constitution by either the history which is being commemorated - the view common to commemorative rhetoric that the past makes the present-or by the present context in which they are produced-the constructivist view that the present makes the past. By looking for minor changes in the repetitions rather than focusing exclusively on the creation of the anniversary or on its present celebration, Bakhtin's view is closely aligned with Koselleck's interest in the changes within the apparently static.

The above reflections are, first, about existing commemorations that are actually celebrated. Just as interesting, however, for the production of historical master narratives are the anniversaries 
of important historical events that for one reason or another never become commemorations, or the commemorations that at a certain point in time cease to be commemorated. After Franco's death in 1975, for example, the anniversaries of the start of the Civil War in 1936 and its end in 1939 were no longer celebrated, but this happened gradually, almost without being noticed, and without any official announcements that the new regime no longer identified with these celebrations. In 1976, the anniversary of the beginning of the Civil War, 18 July, was still a public holiday, but the official celebration disappeared, and, as of 1977, the holiday was eliminated as well. All of this-both the changes in memory practice and the way that these changes are made-is very important for understanding the silences, the continuities, and the discontinuities in the constant (re)construction of the historical master narrative.

It is in many ways paradoxical that Nora invented the 'sites of memory' as a category of analysis, while longing for the kind of temporality and memory practices that existed before these lieux de mémoire became necessary because the continuity between past and present no longer was experienced as natural. Nora saw the sense of continuity created by the 'sites of memory' as artificial, but his conceptualisation of the former 'true' memory practice was highly deficient and contradicts what we know about the historical perception and historiography of pre-modern periods. According to Nora, lieux de mémoire were the result of an increased sense of discontinuity, which means a general change in the perception of temporality and historicity. To be critical of Nora's account of the reasons for this shift in the popular perception of temporality is not necessarily the same, however, as thinking that there was no shift in the perception of time. The increased occurrence of 'sites of memory' from a certain point in time is obviously related to the emergence of the 'imagined communities' - especially the nations-that made it necessary to create a particular type of collective consciousness and memory that had not existed before. Above all, this new consciousness and memory had to be spread to much larger parts of the population than had previously been the case. As Benedict Anderson rightly pointed out, the 'imagined communities' led the linear perception of time to prevail, which is in line with the changes on which Nora's theory rests. However, if the spread of the 'sites of memory' is linked to the rise and success of the 'imagined communities', Nora's nostalgia for pre-modern times no longer makes much sense.

To some extent, it is thus a contradiction in terms to use Nora's concepts and categories in the analysis of master narratives and the social constitution of collective identities. Put bluntly, Nora's project was a crusade against professional historiography and the adjoining social science disciplines, in which there is not just one truth to be found, but many different angles of analysis and (hi)stories that potentially have an equal claim to truth. He was especially critical of the relativism of modern historiography and the prevailing constructivist view of the social sciences. There is, therefore, a good amount of irony in the fact that many constructivists have studied 'sites of memory' to investigate the character of imagined communities as social constructions.

\section{When History and Memory Collide: The Concept of Vergangenheitsbewältigung}

The creation of a master narrative-or its rewriting —also becomes readily available as an object of analysis when it is necessary to settle accounts with the past. Such processes are usually initiated by leading politicians or intellectuals (i.e., from above) or by a popular movement of a certain size (i.e., from below). A revision of the master narrative initiated from below happened when, in 2000, two Spaniards established the Association for the Recuperation of Historical Memory [Asociación para la Recuperación de la Memoria Histórica], the purpose of which was to open the mass graves from the Franco period and the Civil War and to identify as many of the victims as possible. The movement started when one of the founders organised the opening a mass grave where his own grandfather was buried. Shortly after, the founders created a website where people could submit descriptions of what they knew about mass graves and missing people. The website was completely overwhelmed for weeks because their initiative hit a nerve in Spanish society, demonstrating a widespread desire to talk about the past that had been silenced in the transition to democracy (Humlebæk 2011). The result was 
a process in which the previously dominant master narrative was opened up for critical interpretation and a rewriting process was initiated.

The issue of coming to terms with an authoritarian past has been described with the German term Vergangenheitsbewältigung, referring to the post-Second World War process of coming to terms with the past of German society. Losing the war not only resulted in the destruction of the country and the death of millions of Germans, but also in a collective loss of self-respect and moral integrity. The allied victors imposed a narrative according to which the good German people had been hijacked by a group of gangsters. The Nazi period was demonised to save the nation from the heavy burden of moral responsibility and guilt, turning the nation as a whole into a victim of Nazism. In this way, the enormous question of guilt was avoided in the immediate aftermath of the war or at least limited to dealing only with the processes of the Nürnberg trials (Giesen 2000, pp. 240-45). During the first fifteen years, the relationship with the authoritarian past was characterised by silence and repression, not unlike that of the first twenty-odd years after Franco. From around 1960, however, the question of guilt reappeared massively in the public sphere and it led to a rethinking of West Germany's master narrative. This process culminated in the 1970s and 1980s with the question of whether German history had followed a different path than that of its European neighbours, the so-called Sonderweg-debate, which would help to explain the advent of Nazism. The central concern of these efforts was trying to incorporate the period 1933-1945 into a coherent account of German history.

Until the late 1980s, the term Vergangenheitsbewältigung was exclusively related to West Germany, as if it was the only country with a problematic past. The fall of the Berlin Wall in 1989, however, gave new impulse to the theme of Vergangenheitsbewältigung, both internally in Germany as well as in various other countries in the former Eastern Bloc. West Germany was rushing towards annexation of the $\mathrm{DDR}^{8}$, governed by what was considered to be a criminal regime, and it was therefore faced with a new phase of Vergangenheitsbewältigung. Most of the other former Eastern Bloc countries were forced by circumstances to develop ways of dealing with the Communist past, not just in terms of political culture and historical research, but also in terms of the practical political problems that are related to questions of opening archives, taking judicial action against perpetrators, purging public officials of the former regimes, and so forth. These processes happened in varied ways: each country had its own idiosyncrasies when transitioning towards democracy and rebuilding the nation. Some countries had strong historical identities to rediscover and rebuild, whereas others had to reinvent and reimagine themselves much more extensively; but the point here is that the processes almost necessarily involved some way of dealing with the past.

The end of the Cold War, on the other hand, also meant the end to the Second World War as a constitutive category of memory, which caused other European countries that had been occupied by Germany or had maintained neutrality during the war to begin critically examining the less pleasant parts of their respective history, such as in France (König 1998).

In contrast to the former Eastern Bloc countries, Germany already had a model for Vergangenheitsbewältigung derived from the process of denazification in previous decades and the efforts at incorporating the Nazi period into a coherent German history. According to Jeffrey K. Olick, this 'second Vergangenheitsbewältigung' displaced the first, making the confrontation with the Nazi past seem like ancient history. The legacy of Nazism had been moved into history and is no longer considered part of the present. This displacement worked as a powerful normalising agent; Germany was now just one of many countries going through the same problems, and the historical problems of Germany had shifted from Nazism and genocide to those of Communism and State violence. The focus of the Vergangenheitsbewältigung had changed from the problems that are related to National Socialism to those related to Communism (Olick 2003, pp. 269-70).

8 I talk of annexation because technically speaking that was what happened, not a reunion. The two states did not exist before 1949 and had never been united before. Referring to it as reunification can only refer to the experience of the German people. 
Later, the legacy of Nazism entered what could be called the third phase of Vergangenheitsbewältigung, which probably began with the American sociologist and author Daniel Goldhagen's famous 1996 book about what made the Holocaust possible in Germany (Goldhagen 1996). The book triggered a fierce public debate, but the suspicion that the book expressed, i.e., that Nazism was grimmer than previously thought, had been latent in Germany since World War II, according to American-German literature professor Hans Ulrich Gumbrecht. He believes that this latency was having an impact on German cultural identity because the future came to be considered a threat (Gumbrecht 2014) ${ }^{9}$.

The decade-long process of dealing with the past in Germany has naturally resulted in a growing body of theoretical reflection, which has reached the highest level of comparative conceptualisation in the German context. ${ }^{10}$ Helmut König defines the central idea of Vergangenheitsbewältigung in the following terms:

With Vergangenheitsbewältigung is to be understood the totality of action and knowledge with which the new democratic systems relate to their non-democratic predecessor states. Above all, the central question is how the newly established democracies get round the structural, personal and mental legacies of their predecessor states and how in their self-definition and their political culture they relate to their problematic past (König 1998, p. 375).

The overall goal of the processes of Vergangenheitsbewältigung is to make a repetition of the past impossible, thereby bringing about a new political beginning. The means to obtain this are (1) the prohibition of discredited institutions, (2) punishment of perpetrators, (3) disqualification of compromised persons, (4) rehabilitation and compensation for victims, and (5) public exposure of the history of the authoritarian past. In general, the notion of 'historical justice' remains central to Vergangenheitsbewältigung, as does the idea that it is something that has to be done actively: the past has to be faced directly. This schematic outline is, of course, nothing more than a normative description of what Vergangenheitsbewältigung ideally aims to achieve and it seldom responds to reality. Indeed, it is important to keep in mind that the actions undertaken during the first decades of post-Second World War German history, as described above, certainly did not correspond to this description.

The most important shortcoming is that the description does not go much beyond a checklist, and lacks a temporal dimension to explain the evolution of these processes over time, and thus facilitate the evaluation of the processes in course. As was seen above, with the example of Germany, the processes often-and perhaps almost necessarily-evolve through various phases. There thus seems to be a kind of lawfulness to the fact that a certain period of time has to pass before a national community voluntarily faces a problematic or traumatic past, which most probably is related to the processes of generational change. Often, it is simply not possible or even advisable to seek satisfaction of all demands at once, due to the possible consequences in terms of destabilisation.

\section{Comparing Processes of Vergangenheitsbewältigung}

The process of Vergangenheitsbewältigung in itself constitutes an exciting object of analysis if one is interested in master narratives because the very essence of such a process is a struggle over rewriting central parts of the basic narrative of a community. Similarly, comparisons of this kind of process can

9 The suspicions that are the focal point of this third Vergangenheitsbewältigung have in recent years been nourished by the Russian exploration of the newly opened archives. See, for instance, the Russian historian Boris Sokolov's studies of Soviet losses discussed in the dissertation of the Danish political scientist Gorm Harste (Harste 2016). Other examples are the Danish historian Niels Bo Poulsen's recent book on the Eastern front (Poulsen 2016) and the analysis by the German historians Sönke Neitzel and Harald Welzer of the mentality of German soldiers and officers as expressed in interrogation protocols (Neitzel and Welzer 2011).

10 There is a large German literature on Vergangenheitsbewältigung in Germany or on similar processes in other countries. The classical texts by Hermann Lübbe from the early 1980s are still considered valid; see Lübbe (1983a, 1983b). For a status of research on the subject ten years after the fall of the Berlin Wall, see, for example, König et al. (1998). For an account of the politics of memory in Germany, see Camphausen (2002). 
be very exciting because comparisons with other countries' processes are often a key element in the very argument that is used to advocate for adjusting the narrative.

It is important to emphasise that such processes are not just about some more or less random perceptions of the past that are more or less representative of the respective populations, but about active social (re)construction that very often takes place in the form of a struggle around rewriting the master narratives. When the Spaniards themselves compare the transition to democracy as a process of Vergangenheitsbewältigung with other processes of coming to terms with the past, it is usually done to demand a more active - even if only symbolic — confrontation with the problematic legacies of the past. This phenomenon has been termed the 'politics of regret' by the American sociologists Jeffrey K. Olick and Brenda Coughlin. According to these authors, the politics of regret is a major characteristic of our age, and they identify a new principle that makes political legitimacy depend on collective memory (Olick and Coughlin 2003, pp. 37-38). That the demands of the politics of regret are related to a new principle of legitimacy, or at least to attempts at instituting a new principle of legitimacy, fits the Spanish case well. For rhetorical purposes, the Spanish transition is compared with other cases that can be argued to have reached a higher level of Vergangenheitsbewältigung, especially those of Germany and France. References to Germany precisely take advantage of the fact that the process was much more advanced there than in Spain, and Germany's lead of thirty years-which helps to explain Spain's relative delay-is never mentioned.

There are, however, important differences between the cases of Germany and France, which have to be taken into account when making comparisons with Spain. As illustrated above, the victors of the war imposed a history on Germany that absolved the German people from the question of guilt. For approximately the first fifteen years, the relationship with the traumatic past was characterised by a silence not unlike that of post-Franco Spain. Although the difficult past in the case of France also concerned the Second World War, its questions were dealt with in a different way, and above all much later than in Germany. This was principally because France was among the victors of the war, and therefore not forced to deal with the problematic parts of its past by any external power. For the first thirty-odd years, the official history of the Vichy regime was characterised by oblivion. Critical revision only began in the 1970s and it reached a high in the 1990s with the discovery of President François Mitterrand's past as a Vichy official and the trial and conviction of Maurice Papon, a high-ranking Vichy official, for complicity in the persecution of the Jews. As noted above, the end of the Cold War determined this increase in the critical revision of history, which was linked to the end to the Second World War as constitutive category of memory. The delay with respect to these events was thus thirty to fifty years, and actually much longer than the period that had passed in Spain.

It is true that, so far, the process of critically re-examining the past in Spain has not equalled the German or French case. One must bear in mind, however, that the conflict over the past in Spain primarily relates to the Civil War and its long aftermath and only to a lesser extent the last half or more of the dictatorship. As the above shows, however, neither the case of Germany nor that of France is readily comparable to the Spanish situation. Approximately the first fifteen years of German post-war history were characterised by silence, and in France, it took almost thirty years before the first critical voices were heard. In this sense, the first twenty to twenty-five years of Spanish post-Franco memory politics - which mostly dealt with the recent past through silencing-are in many ways comparable to these initial phases of German and French post-war history.

Frequent references to France and Germany, however, also reflect a tradition within Spanish history that at least dates back to the nineteenth century, in which Spain is only compared with the 'great' European powers, thus implicitly counting Spain among those powers (Álvarez Junco 2002). Portugal, for example, a closer parallel to Spain in terms of the events and the epoch in which they took place, is rarely mentioned in these comparisons. This also applies to the twentieth century, where the history of the two countries in many ways followed parallel tracks. Actually, much more has been done in Portugal than in Spain in terms of actively and critically examining the recent past, especially during the years immediately following the revolution, and Portugal would thus seem to 
follow König's model more closely. Purges of public employees took place, and critical publications have since been officially sponsored, both of which would have been unthinkable in Spain due to the gradual and negotiated character of the transition to democracy and the fact that a certain degree of oblivion was part of the implicit agreement between the old and the new regime. In the case of Portugal, the process of Vergangenheitsbewältigung was imposed on society through the revolutionary overturning of power, which differentiates its case from Spain. Furthermore, this coming to terms with the past happened in a rather arbitrary and not very systematic way, especially during the first revolutionary years (Costa Pinto 2001). In fact, the Portuguese revolution, precisely with reference to these aspects, functioned as a strong deterrent in Spain during the transition and helped to reinforce the widespread consensus silencing the past and focusing all attention on the future instead.

Referring to the central questions of the Spanish transition, its experience may actually be more comparable to the recent histories of peace accords and attempts at national reconciliation in, for example, El Salvador and Guatemala. The central issue both in Spain and in the Central American countries was to reconstruct the discourse on the nation after long and bloody civil wars and repressive dictatorships that-with the support of a part of the national community-had practised the elimination of the 'national' adversary. As far as I know, however, no studies have yet undertaken a careful comparison of the historical preconditions for reconciliation in Spain and the Central American countries ${ }^{11}$.

On another level, the Spanish transition has often been referred to as a model for regime change in post-Communist Eastern and Central Europe. The purpose of this comparison was mostly to emulate the negotiated transition from dictatorship to consolidated democracy. Since the German politics of Vergangenheitsbewältigung towards the former DDR regime, involving massive purges and the opening of secret police archives, began so quickly after the fall of the Berlin Wall it also became an unavoidable reference point-in both a positive and negative sense-for the other post-Communist transition regimes. Even if the processes of decommunisation ${ }^{12}$ and transitional justice have not followed the same pattern, in no country was the process characterised by silencing the past, as it had been in both West Germany and Spain ${ }^{13}$. The main reason for this, undoubtedly, is that the historical circumstances in which the post-Communist regimes undertook the transitions to democracy were very different from those of the Cold War, which favoured and even demanded a more active politics of Vergangenheitsbewältigung. All the countries, for example, aspired to become members of the European Union, which therefore was in a position to dictate certain behaviour. Partly as a consequence of this international climate, partly due the direct German interest—both political and academic —in the Eastern and Central European countries, Vergangenheitsbewältigung studies within the Eastern and Central European transitions have developed more quickly and reached a more advanced stage than the same kind of study of the Spanish transition.

In one country, however, the comparison with Spain and the Spanish transition to democracy has been a particularly prominent feature of these discussions, namely in Poland. Here, the comparison with Spain has a long tradition, which at least dates back to the early nineteenth century. ${ }^{14}$ Both Spain

11 For a comparative account of memory politics and the processes of coming to terms with the past in El Salvador, Guatemala, and Honduras, see Sieder (2001).

12 'Decommunisation' is the process of settling the institutional, cultural, and psychological legacy of the communist state of the former communist countries. In comparison to 'denazification', which was imposed by foreign powers-the winners of World War II-'decommunisation' was not forced on the regimes from the outside, and the communist elites have been able to survive the process to varying degrees.

13 For a comparison of decommunisation and attitudes towards transitional justice in Central and Eastern Europe, see González-Enríquez (2001).

14 In 1831, Joachim Lelewel published his thesis Historyczna paralela Hiszpanii z Polska XVI, XVII, XVIII wieku. It has not been translated, but the title reads 'The historical parallel between Spain and Poland in the 16th, 17th, and 18th centuries'; see Kraft (2003, p. 14). For a discussion, in Spanish, of Lelewel's work, see the article from 1991 by the Polish historian Jan Kieniewicz, at the time Polish Ambassador to Spain; see Kieniewicz (1991). He also published the study Hiszpania w zwierciadle polskim [Spain in the Polish mirror] on the image of Spain in Poland and the political use made of it (Kieniewicz 2001). The book is only available in Polish, but a German translation of a conference paper by Kieniewicz 
and Poland share a history of being former empires that suffered a relative marginalisation during the modernisation of Northern Europe in the nineteenth century. Catholicism played an important constituent role in the creation of national self-understanding in rural societies dominated by a powerful agrarian oligarchy. The perceived backwardness of both countries led to debates on the reasons behind this decline and on strategies for modernisation. This is just to mention a few of the basic similarities, which suggest that a comparison of the processes of Vergangenheitsbewältigung during the late twentieth century in Spain and Poland may be based on a background of long-term historical similarities. ${ }^{15}$ This Polish branch of academic studies and the fact that the Spanish transition constitutes a point of reference for comparisons remain largely ignored in Spain.

Returning to the contemporary period, academics consider the transitions to democracy of the two countries to be of roughly the same type - 'internal national reconciliation'16 - that in Spain received the name 'negotiated reform' [reforma pactada] and in Poland 'negotiated revolution'. In practical terms, this meant that for a transitional period the old elites and the former opposition shared power, and that a radical rupture with the former dictatorship had to be avoided. In both countries, the question of retrospective justice was thus excluded almost from the beginning. The first Polish non-communist Prime Minister, Tadeusz Mazowiecki, became famous for declaring that a 'thick line' would be drawn between past and present in his first speech to the Parliament on 24 August 1989:

The Government ( . . ) assumes no responsibility for the mortgage that it inherits. ( ... ) Below the past we will draw a thick line. We shall only be responsible for what we do to get Poland out of the present situation of collapse (Grabowski 1998, quoted in Grabowski 1998, p. 279).

Although this politics was later heavily criticised, the reckoning with the Communist past and retrospective justice in general were never carried through in a thorough way. Over the years, politicians attempted to implement a lustration law various times, but only in 1997 was a heavily watered-down version successfully passed and implemented. According to this law, a Communist past did not entail any consequences; only false declarations regarding the past would be punished. This relatively benign treatment of the Communist past notwithstanding, the reckoning with the past and the issue of decommunisation in general have been a constant issue of debate and is a very divisive element of political life in Poland since the transition (Grabowski 1998; González-Enríquez 2001, pp. 237-41).

\section{Conclusions}

Nations are a kind of collective identity, and, as such, a social phenomenon with concrete political and social effects in society. As has been argued here, however, precisely because they are 'imagined communities', narratives about the collective that disseminate coherent ideas about the fundamental identity of the we-group are a central element in their constitution. Just as important as drawing borders between the collective 'we' and the 'others' is projecting this identity backward in time through the construction of a particular history that places the collective in time with a coherent and logical narrative about the past and a trustworthy projection into the future. The appearance of this kind of historical master narrative mixed new linear temporalities and older, more circular forms

on the book is available in Kieniewicz (2004). See also Kraft (2003) for the use of comparisons with Spain in other Eastern European countries.

15 The research project Diktaturbewältigung und nationale Selbstvergewisserung an der Semi-Peripherie Europas: Geschichtskulturen in Polen und Spanien im Vergleich [Coming to terms with dictatorship and creation of national self-awareness in Europe's semi-periphery: Historical Culture in Spain and Poland in Comparison] at the GWZO Research Centre at Leipzig University was precisely aimed at comparing the Vergangenheitsbewältigung processes in the two countries based on the structural similarities between their histories.

16 In the program of the Eustory congress at the Central European University in Budapest, March 2003, the transition processes of Spain and Poland were grouped together under this heading. 
of temporality, and it was related to the appearance and growth of the nations as a means of social organisation and a mechanism of legitimisation for political power, which has since been dominant. These narratives thus constitute a privileged object for investigating how collective identities are constructed and legitimised.

As the master narrative, at least in principle, penetrates public life on many levels and only shows a limited variation between versions, one can look for the master narrative in a number of places, such as, for example, in official communications from the government and state, in television programmes or series with some historical component, or in discussions of national history among professional historians, as well as lay people. However, to approach the analysis of the core narratives quickly, I have argued here for the usefulness of two research objects. First, are Pierre Nora's 'sites of memory', particularly anniversaries and their celebrations or-just as interesting- the absence of celebration, because they represent the master narrative or relate to it in a very direct manner. Second, are the processes of coming to terms with the past, because these processes are associated with rewriting the master narrative. Although these two categories of research objects thus give easy access to key elements of the master narrative, this does not mean that they are the only possible ways to approach an analysis of it. As mentioned, the possibilities for choosing objects of analysis for studying master narratives are almost legion, but the 'sites of memory' and the Vergangenheitsbewältigung processes work well in giving a direct access to the underlying discourses and arguments that are a constituent part of master narratives.

Funding: This research received no external funding.

Conflicts of Interest: The author declares no conflicts of interest.

\section{References}

Álvarez Junco, José. 2002. La nación española en el debate político y historiográfico del período. Paper presented at the Conference Il dibattito spagnolo sullo stato della Nazione e le nazionalità. II. Gli anni dell'amministrazione socialista (1982-1996), Novi Ligure, Italy, October 25-27.

Anderson, Benedict. 1991. Imagined Communities: Reflections on the Origin and Spread of Nationalism. London: Verso. First published 1983.

Apor, Péter. 2001. Continuity, Lieux de mémoire and Body Politic. Paper presented at the Conference Identity and Temporality. Constructions of Continuity and Discontinuity. European University Institute, Florence, Italy, April 2-3.

Apor, Péter. 2002. Corpus Communismi Mysticum: History, Politics and Continuity in Communist Hungary. Ph.D. dissertation, European University Institute, Florence, Italy.

Camphausen, Gabriele. 2002. Diktaturbewältigung und Erinnerungspolitik in Deutschland und Österreich. Paper presented at the Conference Remembering Dictatorship: Poland and Spain Compared, Santiago de Compostela, Spain, March 15-16.

Chikovani, Nino. 2012. The Georgian historical narrative: From pre-Soviet to post-Soviet nationalism. Dynamics of Asymmetric Conflict: Pathways toward Terrorism and Genocide 5: 107-15. [CrossRef]

Clemens, Gabriele. 2016. "Après avoir créé un commencement d'Europe, il nous faut des Européens". Die Konstruktion einer europäischen Identität durch Europawerbefilme. In Identitäten im Prozess. Region, Nation, Staat, Individuum. Edited by Anna Margretha Horatschek and Anja Pistor-Hatam. Berlin: Walter De Gruyer, pp. 118-36.

Clifton, Jonathan, and Dorien Van De Mieroop. 2016. Master Narratives, Identities, and the Stories of Former Slaves. Amsterdam: John Benjamins Publishing Company.

Corduneanu, Victoria Isabela. 2003. Romanian historical master narrative in the 1970s and 1980s: fabricating heritage. Romanian Journal of Society and Politics 3: 46-76.

Costa Pinto, António. 2001. Settling Accounts with the Past in a Troubled Transition to Democracy: The Portuguese Case. In The Politics of Memory. Transitional Justice in Democratizing Societies. Edited by Alexandra Barahona de Brito, Carmen González-Enríquez and Paloma Aguilar Fernández. Oxford: Oxford University Press, pp. 65-91. 
Giesen, Bernhard. 2000. National Identity as Trauma: The German Case. In Myth and Memory in the Construction of Community: Historical Patterns in Europe and Beyond. Edited by Bo Stråth. Bruxelles: P.I.E.-Peter Lang, pp. 227-47.

Goldhagen, Daniel J. 1996. Hitler's Willing Executioners: Ordinary Germans and the Holocaust. New York: Knopf.

González-Enríquez, Carmen. 2001. De-communization and Political Justice in Central and Eastern Europe. In The Politics of Memory. Transitional Justice in Democratizing Societies. Edited by Alexandra Barahona de Brito, Carmen González-Enríquez and Paloma Aguilar Fernández. Oxford: Oxford University Press, pp. $218-47$.

Grabowski, Sabine. 1998. Vergangenheitsbewältigung in Polen. Dossier und Analyse. In Vergangenheitsbewältigung am Ende des zwanzigsten Jahrhunderts. Edited by Helmut König, Michael Kohlstruck and Andreas Wöll. Opladen: Westdeutscher Verlag, pp. 261-90.

Grosescu, Raluca. 2017. Criminal justice and historical master narratives in post-1989 Bulgaria and Germany. European Politics and Society 18: 66-80. [CrossRef]

Gumbrecht, Hans Ulrich. 2014. After 1945: Latency as Origin of the Present. Stanford: Stanford University Press.

Hadler, Frank. 2002. Drachen und Drachentöter. Das Problem der nationalgeschichtlichen Fixierung in den Historiographien Ostmitteleuropas nach dem Zweiten Weltkrieg. In Die Nation Schreiben. Geschichtswissenschaft im internationalen Vergleich. Edited by Christoph Conrad and Sebastian Conrad. Göttingen: Vandenhoeck \& Ruprecht, pp. 137-64.

Harste, Gorm. 2016. Kritik af Krigens Fornuft. et Perspektiv på Selvreferentielle Systemer fra 11.-21. Århundrede. Århus: Århus Universitetsforlag.

Hernández-Saca, David Isaac. 2016. Re-Framing the Master Narratives of Dis/ability through an Emotion Lens: Voices of Latina/o Students with Learning Disabilities. Ph.D. dissertation, Arizona State University, Tempe, AZ, USA.

Humlebæk, Carsten. 2006. Remembering the Dictatorship. Commemorative Activity in the Spanish Press on the Anniversaries of the Civil War and of the Death of Franco. In Totalitarianism and Authoritarian Regimes in Europe. Legacies and Lessons from the Twentieth Century. Edited by Jerzy Borejsza and Klaus Ziemer. Oxford/New York: Berghahn, pp. 490-515.

Humlebæk, Carsten. 2011. The "pacto del olvido". In The Politics and Memory of Democratic Transition: The Spanish Model. Edited by Gregorio Alonso and Diego Muro. New York and London: Routledge, pp. 183-98.

Jarausch, Konrad H. 2002. Die Krise der nationalen Meistererzählungen. Ein Plädoyer für plurale, interdependente Narrative. In Die historische Meistererzählung Deutungslinien der deutschen Nationalgeschichte nach 1945. Edited by Konrad H. Jarausch and Martin Sabrow. Göttingen: Vandenhoeck \& Ruprecht, pp. 140-62.

Jarausch, Konrad H. 2004. The Return of History-The Unification of German Historiographies and the Search for Master Narratives. Berlin: Wissenschaftszentrum Berlin für Sozialforschung.

Jarausch, Konrad H., and Martin Sabrow. 2002. "Meistererzählung"-Zur Karriere eines Begriffs. In Die historische Meistererzählung Deutungslinien der Deutschen Nationalgeschichte nach 1945. Edited by Konrad H. Jarausch and Martin Sabrow. Göttingen: Vandenhoeck \& Ruprecht, pp. 9-32.

Kieniewicz, Jan. 1991. La obra de Joachim Lelewel: Paralelo histórico entre España y Polonia en los siglos XVI, XVII y XVIII (1831). Hispania 178: 695-734.

Kieniewicz, Jan. 2001. Hiszpania w Zwierciadle Polskim. Gdansk: Wydawnictwo Novis Orbis.

Kieniewicz, Jan. 2004. Spanien im polnischen Spiegel. In Diktaturbewältigung und Nationale Selbstvergewisserung. Geschichtskulturen in Polen und Spanien im Vergleich. Edited by Stefan Troebst and Krzysztof Ruchniewicz. Wroclaw: Wydavnictwo Uniwersytetu Wrocławskiego, pp. 15-23.

König, Helmut. 1998. Von der Diktatur zur Demokratie oder Was ist Vergangenheitsbewältigung. In Vergangenheitsbewältigung am Ende des Zwanzigsten Jahrhunderts. Edited by Helmut König, Michael Kohlstruck and Andreas Wöll. Opladen: Westdeutscher Verlag, pp. 371-92.

König, Helmut, Michael Kohlstruck, and Andreas Wöll, eds. 1998. Vergangenheitsbewältigung am Ende des zwanzigsten Jahrhunderts. Opladen: Westdeutscher Verlag.

Koselleck, Reinhardt. 2000. Zeitschichten. Studien zur Historik mit Einem Beitrag von Hans-Georg Gadamer. Frankfurt a.M.: Suhrkamp.

Kraft, Claudia. 2003. “Europäische Peripherien”-“Europäische Identität”: Über den Umgang mit der Vergangenheit im zusammenwachsenden Europa. Jahrbuch für Europäische Geschichte 4: 11-37.

Lübbe, Hermann. 1983a. Der Nationalsozialismus im deutschen Nachkriegsbewusstsein. Historische Zeitschrift 236: 579-99. [CrossRef] 
Lübbe, Hermann. 1983b. Der Nationalsozialismus im politischen Bewusstsein der Gegenwart. In Deutschlands Weg in die Diktatur. Internationale Konferenz zur nationalsozialistischen Machtübernahme. Edited by Martin Broszat, Walther Hofer, Ulrich Dübber, Horst Möller, Heinrich Oberreuther, Jürgen Schmädeke and Wolfgang Treue. Berlin: Siedler Verlag, pp. 329-49.

Lyotard, Jean-François. 1979. La Condition Postmoderne-Rapport sur le Savoir. Paris: Éditions de Minuit.

Megill, Alan. 1995. 'Grand Narrative' and the Discipline of History. In A New Philosophy of History. Edited by Frank Ankersmit and Hans Kellner. Chicago: University of Chicago Press, pp. 151-73.

Middell, Matthias, Monika Gibas, and Frank Hadler. 2000. Sinnstiftung und Systemlegitimation durch historisches Erzählen. Überlegungen zu Funktionsmechanismen von Repräsentationen des Vergangenen. Comparativ 10: 7-35.

Neitzel, Sönke, and Harald Welzer. 2011. Soldaten: Protokolle vom Kämpfen, Töten und Sterben. Frankfurt a.M.: S. Fischer Verlage.

Nora, Pierre, ed. 1984-1992. Les lieux de Mémoire. 7 vols. Paris: Gallimard.

Nora, Pierre. 1989. Between Memory and History: Les Lieux de Mémoire. Representations 26: 7-25. [CrossRef]

Nora, Pierre. 1996. General Introduction: Between Memory and History. In Realms of Memory: Rethinking the French Past. Volume 1. Conflicts and Divisions. Edited by Pierre Nora. New York: Columbia University Press, pp. 1-20.

Olick, Jeffrey K. 1999. Genre memories and memory genres: A dialogical analysis of May 8, 1945 commemorations in the Federal Republic of Germany. American Sociological Review 64: 381-402. [CrossRef]

Olick, Jeffrey K. 2003. What Does It Mean to Normalise the Past? Official Memory in German Politics since 1989. In States of Memory. Continuities, Conflicts, and Transformations in National Retrospection. Edited by Jeffrey K. Olick. Durham: Duke University Press, pp. 259-88.

Olick, Jeffrey K., and Brenda Coughlin. 2003. The Politics of Regret. Analytical Frames. In Politics and the Past: On Repairing Historical injustices. Edited by John Torpey. Lanham: Rowman and Littlefield, pp. 37-62.

Poulsen, Niels Bo. 2016. Skæbnekamp. Den tysk-sovjetiske krig 1941-1945. Copenhagen: Gyldendal.

Renan, Ernest. 1992. Qu'est-ce Qu'une Nation? Paris: Presses-Pocket. First published 1882.

Sider, Gerald, and Gavin Smith. 1997. Introduction. In Between History and Histories: The Making of Silences and Commemorations. Edited by Gerald Sider and Gavin Smith. Toronto: University of Toronto Press, pp. 3-28.

Sieder, Rachel. 2001. War, Peace, and Memory Politics in Central America. In The Politics of Memory. Transitional Justice in Democratizing Societies. Edited by Alexandra Barahona de Brito, Carmen González-Enríquez and Paloma Aguilar Fernández. Oxford: Oxford University Press, pp. 161-89.

Till, Karen E. 2003. Places of Memory. In A Companion to Political Geography. Edited by John Agnew, Katharyne Mitchell and Gerard Toal. Malden: Blackwell, pp. 289-301.

Trouillot, Michel-Rolph. 1995. Silencing the Past: Power and the Production of History. Boston: Beacon Press.

White, Hayden. 1973. Metahistory. The Historical Imagination in Nineteenth Century Europe. Baltimore: Johns Hopkins University Press.

Olick, Jeffrey K. 2003. Calendars and History: A Comparative Study of the Social Organization of National Memory. In States of Memory. Continuities, Conflicts, and Transformations in National Retrospection. Olick, Jeffrey K. Durham: Duke University Press, pp. 315-37.

(C) 2018 by the author. Licensee MDPI, Basel, Switzerland. This article is an open access article distributed under the terms and conditions of the Creative Commons Attribution (CC BY) license (http://creativecommons.org/licenses/by/4.0/). 